\title{
Aetiological role of bacteria associated with reactive arthritis in pauciarticular juvenile chronic arthritis
}

\author{
J Sieper, J Braun, E Döring, P Wu, J Heesemann, J Treharne, G Kingsley
}

Department of Medicine, Klinikum Steglitz, Free University of Berlin, Germany

J Sieper

J Braun

Kinderklinik, Klinikum Buch, Berlin, Germany E Döring

Deutsches Rheumaforschungszentrum Berlin, Germany P Wu

Institute of Hygiene and Microbiology,

University of Würzburg, Germany

J Heesemann

Institute of

Ophthalmology, London,

United Kingdom

J Treharne

Rheumatology Unit, Department of Medicine, Guy's Hospital, London, United Kingdom G Kingsley

Correspondence to: Dr Joachim Sieper, Medizinische Klinik Medizinische KK,
und Poliklinik, Klinikum Steglitz, Hindenburgdamm 30 W 1000 Berlin 45, Germany.

Accepted for publication 6 July 1992

\begin{abstract}
Background The cause of juvenile chronic arthritis (JCA) is unknown. Pauciarticular JCA is the most common subtype and can be subdivided into early (type I) and late onset (type II) forms, the latter clinically resembling reactive arthritis.
\end{abstract}

Methods The cellular immune responses to bacteria associated with reactive arthritis in blood and synovial fluid from 39 children with pauciarticular JCA, three children with classical reactive arthritis, and two children with psoriatic arthritis were examined. Specific titres of antibodies to bacteria in serum samples were measured in all patients.

Results A bacteria specific synovial cellular immune response was found in two of three $(67 \%)$ patients with reactive arthritis and 14 of $28(50 \%)$ patients with pauciarticular JCA type II but only in one of $11(9 \%)$ patients with pauciarticular JCA type I and none in patients with psoriatic arthritis. Six patients responded specifically to Chlamydia trachomatis and 11 to Yersinia enterocolitica. Antigen specific lymphocyte proliferation correlated poorly with the specific antibody response.

Conclusions These findings suggest that bacteria with associated reactive arthritis may have a causative role in pauciarticular JCA type II but not in JCA type I.

(Ann Rheum Dis 1992; 51: 1208-1214)

Juvenile chronic arthritis (JCA) is defined as arthritis beginning before the age of 16 and lasting at least three months. ${ }^{1}$ It is divided into pauciarticular, polyarticular, and systemic forms of which the most common, accounting for $50 \%$ of patients, is pauciarticular JCA. ${ }^{2}$ This is further subdivided into early onset pauciarticular JCA (type I), which primarily affects young girls and is associated with antinuclear antibodies and chronic iridocyclitis, and late onset pauciarticular JCA (type II) which occurs mainly in older HLA-B27 positive boys who may develop spondyloarthropathy. ${ }^{3}$ These subtypes are heterogeneous, however, overlap between them and spondyloarthropathies is common. Spondyloarthropathies account for up to $10 \%$ of the incidence of arthritis in children ${ }^{3-5}$ and, in addition to psoriatic arthritis, reactive arthritis, ankylosing spondylitis, and enteropathic arthritis, include atypical spondyloarthropathy, which is often classified as pauciarticular JCA. There is also a clinical similarity between reactive arthritis and certain cases of pauciarticular JCA type II, which are often self limiting, affect mainly the legs and may include features of spondyloarthropathy.

The aetiopathogenesis of $\mathrm{JCA}^{6}$ is unknown. In support of a general pathogenetic role for $T$ cells, synovial T cells in patients with JCA are activated and enriched for $\gamma-\delta$ T cells. ${ }^{78}$ However, the various subgroups appear to have distinct aetiologies because they are not only clinically but also immunologically ${ }^{29}$ and genetically ${ }^{10}$ distinct.

The idea that infection may play a part in the aetiology of JCA is not new. Many viruses, notably rubella and parvovirus, cause a transient arthritis. Whether viruses are involved in JCA is less clear, ${ }^{11}$ though there is evidence for rubella $^{12}$ and influenza $A .{ }^{13}$ Less attention has been paid to bacteria, except in studies of reactive arthritis. Antibodies to peptidoglycan, a bacterial cell wall constituent, have been reported in juvenile ankylosing spondylitis and pauciarticular JCA. ${ }^{14}$ Some work ${ }^{15}$ has shown that $\mathrm{T}$ cells from patients with JCA proliferate to mycobacterial 65 kilodalton heat shock protein (hsp) and to the homologous human hsp60. Although this reactivity may be perpetuated by abnormal expression of human hsp60 in the joint, acting as an autoantigen, it could be initiated by infection as all bacteria have proteins from this conserved family.

Owing to its clearly defined cause, there has been considerable interest in the pathogenesis of reactive arthritis. ${ }^{16}$ In adults Chlamydia trachomatis, Yersinia enterocolitica, salmonella, shigella, and campylobacter are common causes. ${ }^{17}$ In children, reactive arthritis accounts for $5-10 \%$ of the cases of arthritis. ${ }^{4}{ }^{18}$ Common triggers include $Y$ enterocolitica and salmonella ${ }^{19}$ but cases due to $C$ trachomatis have also been described. ${ }^{20} 21$ Borrelia burgdorferi may induce reactive arthritis but may also cause arthritis by other means such as direct infection. ${ }^{22}$

There is considerable evidence that the initiating infection is often subclinical ${ }^{16 \quad 17}$ and it is therefore likely that many cases of reactive arthritis in children, as in adults, ${ }^{23}{ }^{24}$ are not diagnosed as such. The advantages and disadvantages of the various diagnostic methods have been discussed in detail elsewhere and will not be considered in depth here. ${ }^{162325}$ The triggering organisms cannot be cultured from the joint in reactive arthritis ${ }^{26} 27$ and urethral swabs and stool cultures are often negative by the time the arthritis develops. ${ }^{17}$ Antibody titres are also unreliable, giving false negative and false positive results. ${ }^{28-30}$ It has been shown that, in reactive arthritis, synovial $T$ cells respond specifically to the triggering bacterium. ${ }^{29} 3132$ Synovial lymphocyte prolifera- 
tion to bacterial antigens can thus be used to indicate the identity of the triggering organism. ${ }^{16}$

We have studied the proliferative response of synovial mononuclear cells from patients with JCA to a range of bacterial antigens. Our study provides unique evidence of synovial $T$ cell reactivity to bacteria which trigger reactive arthritis in a subset of patients with pauciarticular JCA type II, which is associated with HLA-B27 and bears considerable resemblance to adult undifferentiated oligoarthritis; such specific reactivity is found only rarely in patients with pauciarticular JCA type I.

\section{Patients and methods PATIENTS}

Forty two consecutive children (18 girls, 24 boys; mean age 11, range 3-19 years) attending a general paediatric rheumatology clinic were investigated. Patients were included if they met the criteria for pauciarticular JCA or classical reactive arthritis, as defined in the following, and presented with a knee effusion. Two patients with psoriatic arthritis, diagnosed by the presence of typical skin lesions or nail changes, and knee effusions were also studied as controls. Table 1 gives the characteristics of these patients. Paired peripheral blood and synovial fluid samples were obtained from each patient during diagnostic or therapeutic aspiration and the blood or synovial fluid was taken into sterile containers with $10 \mathrm{U} / \mathrm{ml}$ preservative free heparin (Braun, Melsungen, Germany). Blood samples were also obtained from nine normal control subjects from the same area (four girls, five boys; mean age $8 \cdot 6$, range $3-16$ years).

Classical reactive arthritis was defined as an oligoarthritis preceded by a clear history of urethritis or gastroenteritis in the previous four weeks. ${ }^{17}$ Juvenile chronic arthritis was defined as arthritis affecting one or more joints, beginning before the age of 16 years, and lasting more than three months, other causes of arthritis having been excluded; ${ }^{1}$ it was further divided into systemic JCA (fever and rash at onset), polyarticular JCA (five or more joints affected in the first six months of the disease) and pauciarticular JCA (four or less joints affected in the first six months of the disease). Children with polyarticular and systemic forms of the disease were excluded from the study. Pauciarticular JCA was subdivided ${ }^{3}$ into type I (presence of antinuclear antibodies or a history of chronic iridocyclitis, or both) and type II (absence of these features).

The study patients were subdivided prospec- tively into three major groups: (a) classical reactive arthritis, three children; $(b)$ pauciarticular JCA type I, 11 children; and (c) pauciarticular JCA type II, 28 children. All children with JCA type I were HLA-B27 negative; two in the reactive arthritis group were HLA-B27 positive. From the children with JCA type II, 14 were HLA-B27 positive and 14 were HLA-B27 negative.

Atypical or undifferentiated spondyloarthropathy ${ }^{33}$ was diagnosed when European spondylarthropathy study group criteria were met $^{34}$ but not the full criteria for ankylosing spondylitis, reactive arthritis or psoriatic arthritis; similar criteria have been proposed for children. ${ }^{5}$

\section{CELL SEPARATION AND CULTURE}

Mononuclear cells were separated as described previously ${ }^{29}$ from paired samples of peripheral blood and synovial fluid by density gradient centrifugation (Lymphoprep, Nycomedas, Norway) and resuspended at $2 \times 10^{6}$ cells $/ \mathrm{ml}$ in tissue culture medium consisting of RPMI 1640 (Gibco, Paisley, UK) with $10 \%$ fetal calf serum (Gibco), penicillin/streptomycin (100 U/100 $\mu \mathrm{g} / \mathrm{ml}$; Biochrom, Berlin, Germany) and glutamine ( $2 \mathrm{mM} / \mathrm{ml}$; Biochrom). Cells were aliquoted into 96 well plates at $2 \times 10^{5}$ cells/well and cultured for six days in a $5 \%$ carbon dioxide incubator. Triplicate wells were stimulated with some or all of the following agents: tissue culture medium alone (background proliferation); Chlamydia trachomatis serovar L1 (5 $\mu \mathrm{g} / \mathrm{ml})$, grown and purified as described previously: ${ }^{35}$ Yersinia enterocolitica $(0.3$ and 0.9 $(3 \mu \mathrm{g} / \mathrm{ml})$, grown in trypticase soya bouillon over 48 hours and washed in phosphate buffered saline; Salmonella enteritidis $(5 \mu \mathrm{g} / \mathrm{ml})$, Shigella flexneri $(5 \mu \mathrm{g} / \mathrm{ml})$, Campylobactert jejuni $(5 \mu \mathrm{g} / \mathrm{ml})$, grown in broth, boiled for one hour to inactivate them, then washed and tested for sterility by culturing a sample; Borrelia burgdorferi $(5 \mu \mathrm{g} / \mathrm{ml})$, isolation B29 from a Berlin tick, grown in Kelly's medium and washed in phosphate buffered saline; ${ }^{36}$ tetanus toxoid (Behring, Marburg, Germany, $1 \mu \mathrm{g} / \mathrm{ml}$ ); or pokeweed mitogen (Sigma, Poole, UK, $1 \mu \mathrm{g} / \mathrm{ml}$ ).

Wells were pulsed with $\left[{ }^{3} \mathrm{H}\right]$ thymidine $(7 \cdot 4$ $\mathrm{kBq} /$ well) for the last 18 hours of culture and incorporation measured at day 6 as described previously. ${ }^{29}$ The optimum dose and time for proliferation assays were investigated in preliminary experiments (data not shown) and stimulation was carried out with whole bacteria. $C$ trachomatis, $Y$ enterocolitica, and $B$ burgdorferi were tested in all patients as $C$ trachomatis and $Y$ enterocolitica are the most common causes of

Table 1 Characteristics of patients with juvenile arthritis in different subgroups

\begin{tabular}{lcccccc}
\hline & Girls/boys & $\begin{array}{l}\text { Mean(range) } \\
\text { current age } \\
\text { (years) }\end{array}$ & $\begin{array}{l}\text { Mean(range) } \\
\text { age at onset } \\
\text { (years) }\end{array}$ & $\begin{array}{l}\text { No of patients } \\
\text { positive for } \\
\text { antinuclear } \\
\text { antibodies }\end{array}$ & $\begin{array}{l}\text { No of patients } \\
\text { with irido- } \\
\text { cyclitis }\end{array}$ & $\begin{array}{l}\text { Noof patients } \\
\text { HLA-B27 } \\
\text { positive }\end{array}$ \\
\hline Reactive arthritis $(n=3)$ & $0 / 3$ & $13 \cdot 3(8-17)$ & $11 \cdot 7(7-15)$ & 0 & 0 & 2 \\
JCA type I $(n=11)^{*}$ & $9 / 2$ & $10 \cdot 5(6-14)$ & $4 \cdot 9(4-9)$ & 9 & 6 & 0 \\
JCA type II, B27 positive $(n=14)^{*}$ & $3 / 11$ & $11 \cdot 4(6-19)$ & $9 \cdot 3(2-14)$ & 0 & 0 & 0 \\
JCA type II, B27 negative $(n=14)^{*}$ & $6 / 8$ & $11 \cdot 1(3-17)$ & $8 \cdot 6(2-13)$ & 0 & 0 & 0 \\
Psoriatic arthritis $(n=2)$ & $1 / 1$ & $8(7-9)$ & $6 \cdot 5(6-7)$ & 0 & 0 & 16 \\
All patients $(n=44)$ & $19 / 25$ & $11 \cdot 0(3-19)$ & $8 \cdot 1(2-15)$ & 9 & 6 & 0 \\
\hline
\end{tabular}

${ }^{*} \mathrm{JCA}=$ juvenile chronic arthritis 
reactive arthritis in Berlin ( $\mathrm{J}$. Sieper, unpublished data); salmonella, campylobacter, and shigella were tested when cells were available.

Results are expressed as $\left[{ }^{3} \mathrm{H}\right]$ thymidine incorporation in counts/min (cpm) or in stimulation indices (SI). Stimulation indices, defined as the proliferation induced by an antigen divided by the background proliferation, were also used to define the positivity and specificity of responses as follows: SI greater than or equal to 5 were considered positive. If responses to two or more antigens were positive, the highest SI had to be double the value of the next highest to be considered specific, otherwise this was regarded as a non-specific response. Subjects with SI less than 5 for all pathogens were considered to be non-responders.

To exclude the possibility that a higher response in synovial fluid compared with peripheral blood was due simply to recruitment of memory or activated $\mathrm{T}$ cells into inflammatory lesions by mechanisms unrelated to the triggering antigens, ${ }^{16}$ synovial fluid and peripheral blood from all patients were tested with the recall antigen tetanus toxoid to which the German population is routinely immunised.

\section{MEASUREMENT OF ANTIBODY TITRES}

IgG, IgM, and IgA antibodies to chlamydia were measured by standardised microimmunofluorescence as described previously. ${ }^{37}$ The following serotypes were used as antigens: Chlamydia trachomatis (serotypes A-C, D-K, L1-L3), Chlamydia pneumoniae (TWAR; isolates TWI 183 and IOL-207), and a pool of Chlamydia psittaci isolates (human $33 / \mathrm{L}$ and IOL-395, cat 457-F, sheep abortion A-22, pigeon SDP-247). Titres were considered to be positive when $\geqslant 1 / 64$ for IgG and $\geqslant 1 / 16$ for IgA and IgM.

Titres of IgA and IgG antibodies against yersinia were estimated by immunoblotting; $;^{30}$ only $\operatorname{Ig} A \geqslant 1 / 200$ or $\operatorname{IgG} \geqslant 1 / 200$ were considered positive. Antibodies to $B$ burgdorferi were measured by indirect immunofluorescence (positive $\geqslant 1 / 128$ ) and, for samples positive by immunofluorescence, by enzyme linked immunosorbent assay (ELISA) to differentiate between IgG and IgM antibodies. ${ }^{38}$ Antibodies to salmonella were measured by ELISA and to campylobacter by immunoblotting. Antibodies to shigella were not measured.

Rheumatoid factor was measured by the standard Rose-Waaler test. Antinuclear antibodies were estimated by indirect immunofluorescence using Hep 2 cells as substrate and a titre $\geqslant 1 / 160$ was considered positive.

HLA TYPING

Limited HLA typing for HLA-B27 was performed using the standard microlymphocytoxicity test. ${ }^{39}$

STATISTICAL METHODS

The Fisher $2 \times 2$ test was used to analyse the differences between the groups.

\section{Results}

SYNOVIAL FLUID AND PERIPHERAL BLOOD

RESPONSES TO TETANUS TOXOID

To exclude the possibility that antigen responses are always non-specifically increased in synovial fluid with respect to peripheral blood we compared synovial fluid and peripheral blood mononuclear cell responses to tetanus toxoid, an antigen not thought to play any part in arthritis. Table 2 gives the results. Twenty one $(50 \%)$ of these patients responded to tetanus toxoid in their peripheral blood and 24 of 42 $(57 \%)$ in the synovial fluid with an $\mathrm{SI} \geqslant 5$. Fourteen (33\%) showed a synovial fluid response in the absence of a response in peripheral blood and $10(24 \%)$ showed a peripheral blood response in the absence of a synovial fluid response. Furthermore, in the whole group the synovial fluid response to tetanus toxoid was greater than that in peripheral blood in $18 / 42(43 \%)$, whereas the peripheral blood response was greater in 17 of $42(40 \%)$. In seven patients the SI was $<5$ in peripheral blood and synovial fluid. Taken together these data do not support the proposal of a general increase in antigen responses in synovial fluid compared with peripheral blood.

Table 2 Lymphocyte proliferation to tetanus toxoid (TT) in patients with reactive arthritis and juvenile chronic arthritis $(\mathfrak{F C A})$. Results expressed as $\left[{ }^{3} \mathrm{H}\right]$ thymidine incorporation $\left(\mathrm{cpm} \times 10^{-3}\right)$

\begin{tabular}{|c|c|c|c|c|}
\hline \multirow{2}{*}{$\begin{array}{l}\text { Patient } \\
\text { No }\end{array}$} & \multicolumn{2}{|c|}{ Synovial fluid } & \multicolumn{2}{|c|}{ Peripheral blood } \\
\hline & Medium & $T T$ & Medium & $T T$ \\
\hline $\begin{array}{c}\text { Reactive } \\
\quad 1 \\
2 \\
3\end{array}$ & $\begin{array}{l}\text { s } \\
0.2 \\
0.4 \\
0.3\end{array}$ & $\begin{array}{r}0.1 \\
9 \cdot 4 \\
10.5\end{array}$ & $\begin{array}{l}2 \cdot 3 \\
0 \cdot 1 \\
0 \cdot 2\end{array}$ & $\begin{array}{r}5.8 \\
13.2 \\
5.5\end{array}$ \\
\hline $\begin{array}{c}\mathcal{F} C A \text { typ } \\
4 \\
5 \\
6 \\
7 \\
8 \\
9 \\
10 \\
11 \\
12 \\
13 \\
14\end{array}$ & $\begin{array}{l}3.4 \\
4.3 \\
1.7 \\
0.3 \\
0.3 \\
0.5 \\
1.2 \\
1.9 \\
0.8 \\
1.5 \\
2 \cdot 2\end{array}$ & $\begin{array}{r}16.3 \\
14.3 \\
9 \cdot 2 \\
19 \cdot 1 \\
6.2 \\
23.5 \\
7.9 \\
5.7 \\
7.9 \\
17.6 \\
32.6\end{array}$ & $\begin{array}{l}6.3 \\
2 \cdot 1 \\
3.6 \\
3.1 \\
2.6 \\
4.7 \\
0.5 \\
0.8 \\
1.3 \\
4.4 \\
5.9\end{array}$ & $\begin{array}{r}7.8 \\
13.5 \\
6.4 \\
9.9 \\
7.5 \\
14.6 \\
11.9 \\
6.8 \\
4.3 \\
10.6 \\
16.8\end{array}$ \\
\hline
\end{tabular}

\section{JCA type II, HLA-B27 positive}

\begin{tabular}{|c|c|c|c|c|}
\hline \multicolumn{5}{|c|}{ fСA tуре II, Н } \\
\hline 15 & $2 \cdot 4$ & $4 \cdot 9$ & $2 \cdot 2$ & $11 \cdot 9$ \\
\hline 16 & $1 \cdot 3$ & $4 \cdot 6$ & $1 \cdot 0$ & $5 \cdot 0$ \\
\hline 17 & 0.8 & 3.9 & 0.4 & $4 \cdot 0$ \\
\hline 18 & $1 \cdot 2$ & 11.9 & $1 \cdot 3$ & $15 \cdot 7$ \\
\hline 19 & $1 \cdot 7$ & $3 \cdot 0$ & $3 \cdot 8$ & $3 \cdot 8$ \\
\hline 20 & $1 \cdot 5$ & $12 \cdot 6$ & $5 \cdot 7$ & $13 \cdot 9$ \\
\hline 21 & 1.9 & $11 \cdot 8$ & $4 \cdot 2$ & $4 \cdot 4$ \\
\hline 22 & $1 \cdot 1$ & 1.5 & 0.4 & $6 \cdot 1$ \\
\hline 23 & $1 \cdot 2$ & $17 \cdot 1$ & $2 \cdot 1$ & $8 \cdot 7$ \\
\hline 24 & $1 \cdot 1$ & 1.4 & $2 \cdot 6$ & $4 \cdot 1$ \\
\hline 25 & $0 \cdot 4$ & $14 \cdot 5$ & $0 \cdot 2$ & $14 \cdot 9$ \\
\hline 26 & $0 \cdot 4$ & $8 \cdot 5$ & $1 \cdot 1$ & $4 \cdot 0$ \\
\hline 27 & $1 \cdot 1$ & $2 \cdot 3$ & 0.9 & $3 \cdot 3$ \\
\hline 28 & $2 \cdot 0$ & $5 \cdot 7$ & $2 \cdot 1$ & $3 \cdot 2$ \\
\hline \multicolumn{5}{|c|}{ FCA type II, HLA-B27 negative } \\
\hline 29 & $1 \cdot 2$ & $5 \cdot 0$ & 0.5 & $11 \cdot 9$ \\
\hline 30 & $1 \cdot 7$ & $13 \cdot 4$ & 0.9 & $14 \cdot 6$ \\
\hline 31 & 1.8 & $6 \cdot 8$ & $3 \cdot 1$ & $7 \cdot 4$ \\
\hline 32 & 0.2 & 0.6 & 0.4 & $2 \cdot 3$ \\
\hline 33 & 0.5 & 14.9 & $2 \cdot 6$ & $23 \cdot 5$ \\
\hline 34 & 1.9 & $3 \cdot 7$ & 0.8 & 6.5 \\
\hline 35 & 0.5 & $17 \cdot 3$ & 0.9 & $14 \cdot 5$ \\
\hline 36 & 1.5 & $22 \cdot 6$ & $4 \cdot 4$ & $25 \cdot 7$ \\
\hline 37 & 0.8 & $2 \cdot 3$ & $13 \cdot 3$ & $19 \cdot 9$ \\
\hline 38 & $0 \cdot 2$ & 0.7 & 0.6 & $4 \cdot 5$ \\
\hline 39 & 0.8 & $10 \cdot 8$ & 0.3 & $4 \cdot 1$ \\
\hline 40 & 0.6 & $2 \cdot 1$ & 0.9 & $16 \cdot 3$ \\
\hline 41 & 1.6 & $9 \cdot 3$ & 0.3 & $14 \cdot 2$ \\
\hline 42 & 1.9 & $25 \cdot 4$ & 5.9 & 18.7 \\
\hline
\end{tabular}


SYNOVIAL CELLULAR IMMUNE RESPONSE TO BACTERIAL ANTIGENS

Two of three $(67 \%)$ patients with reactive arthritis had a specific immune response to $C$ trachomatis or $Y$ enterocolitica; the remaining patient had a non-specific immune response (table 3 ). The two patients with psoriatic arthritis had a negative response $(\mathrm{SI}<4)$ to all antigens tested. In 39 children with pauciarticular JCA, $15(38 \%)$ had a specific response to $Y$ enterocolitica or $C$ trachomatis and $16(41 \%)$ showed a non-specific response to several antigens. Only eight (21\%) showed no response to any antigen (table 3 ).

The most interesting results were obtained when patients with JCA were subdivided into types I and II. In JCA type I only one child (9\%) showed an antigen specific immune response to $Y$ enterocolitica; 10 of $11(91 \%)$ had a non-specific response. In contrast, $14(50 \%)$ of

Table 3 Synovial lymphocyte response to yersinia $(Y E)$, chlamydia $(C T)$, borrelia $(B B)$, salmonella $(S A)$, shigella $(S H)$, and campylobacter $(C \mathcal{F})$ in patients with reactive arthritis and juvenile chronic arthritis (fCA). Results are expressed as $\left[{ }^{3} \mathrm{H}\right]$ thymidine incorporation $\left(\mathrm{cpm} \times 10^{-3}\right)$; specific responses are in bold type

\begin{tabular}{|c|c|c|c|c|c|c|c|}
\hline Patient No & Medium & $Y E$ & $C T$ & $B B$ & $S A$ & $S H$ & $C \mathcal{F}$ \\
\hline $\begin{array}{c}\text { Reactive art } \\
1 \\
2 \\
3\end{array}$ & $\begin{array}{c}\text { ritis } \\
0.2 \\
0.4 \\
0.5\end{array}$ & $\begin{array}{l}6 \cdot 2 \\
8 \cdot 5 \\
3 \cdot 0\end{array}$ & $\begin{array}{r}0.6 \\
19.0 \\
3 \cdot 1\end{array}$ & $\begin{array}{l}0.5 \\
6 \cdot 2 \\
2 \cdot 0\end{array}$ & $\begin{array}{l}1.6 \\
\text { ND } \\
\text { ND }\end{array}$ & $\begin{array}{r}2 \cdot 0 \\
\text { ND } \\
\text { ND }\end{array}$ & $\begin{array}{l}0.8 \\
\text { ND } \\
\text { ND }\end{array}$ \\
\hline $\begin{array}{c}f C A \text { type I } \\
4 \\
5 \\
6 \\
7 \\
8 \\
9 \\
10 \\
11 \\
12 \\
13 \\
14\end{array}$ & $\begin{array}{l}3.4 \\
4.3 \\
1.7 \\
0.3 \\
0.4 \\
0.5 \\
1.2 \\
2.0 \\
0.8 \\
1.5 \\
2.2\end{array}$ & $\begin{array}{l}17 \cdot 0 \\
20 \cdot 0 \\
36 \cdot 0 \\
14 \cdot 0 \\
41 \cdot 0 \\
25 \cdot 0 \\
13 \cdot 0 \\
12 \cdot 0 \\
13 \cdot 0 \\
11 \cdot 0 \\
23 \cdot 0\end{array}$ & $\begin{array}{r}21 \cdot 0 \\
15 \cdot 0 \\
24.0 \\
25.0 \\
23.0 \\
17.0 \\
14.0 \\
17.0 \\
1.3 \\
1.8 \\
11.0\end{array}$ & $\begin{array}{r}8 \cdot 4 \\
10 \cdot 0 \\
7 \cdot 1 \\
13 \cdot 0 \\
14 \cdot 0 \\
8 \cdot 4 \\
8 \cdot 2 \\
4 \cdot 7 \\
4 \cdot 5 \\
8 \cdot 0 \\
8 \cdot 3\end{array}$ & $\begin{array}{c}\mathrm{ND} \\
8 \cdot 0 \\
10 \cdot 0 \\
\mathrm{ND} \\
29 \cdot 0 \\
\mathrm{ND} \\
1 \cdot 7 \\
24 \cdot 0 \\
5 \cdot 7 \\
\mathrm{ND} \\
14 \cdot 0\end{array}$ & $\begin{array}{r}\text { ND } \\
9 \cdot 0 \\
12 \cdot 0 \\
\text { ND } \\
22 \cdot 0 \\
\text { ND } \\
2 \cdot 9 \\
2 \cdot 6 \\
4 \cdot 0 \\
\text { ND } \\
22 \cdot 0\end{array}$ & $\begin{array}{r}\text { ND } \\
8.0 \\
7.5 \\
\text { ND } \\
3.9 \\
\text { ND } \\
3.4 \\
2.6 \\
2.1 \\
\text { ND } \\
8.0\end{array}$ \\
\hline $\begin{array}{c}\text { FCA type II } \\
15 \\
16 \\
17 \\
18 \\
19 \\
20 \\
21 \\
22 \\
23 \\
24 \\
25 \\
26 \\
27 \\
28\end{array}$ & $\begin{array}{l}H L A-B 27 \\
2 \cdot 4 \\
0.8 \\
0.3 \\
1.2 \\
1.7 \\
1.5 \\
1.9 \\
1 \cdot 1 \\
1.2 \\
1.1 \\
0.4 \\
0.4 \\
1.1 \\
2.1\end{array}$ & $\begin{array}{r}23 \cdot 0 \\
5 \cdot 2 \\
3 \cdot 4 \\
7 \cdot 0 \\
29 \cdot 0 \\
16 \cdot 0 \\
3 \cdot 2 \\
2 \cdot 8 \\
5 \cdot 1 \\
4 \cdot 1 \\
3 \cdot 0 \\
6 \cdot 2 \\
4 \cdot 1 \\
4 \cdot 1\end{array}$ & $\begin{array}{r}3 \cdot 1 \\
2 \cdot 3 \\
4 \cdot 7 \\
3 \cdot 2 \\
18.0 \\
12 \cdot 0 \\
1.8 \\
5.8 \\
15.0 \\
5.9 \\
9.3 \\
0.9 \\
2 \cdot 4 \\
2.8\end{array}$ & $\begin{array}{r}4.1 \\
1.8 \\
2.9 \\
\text { ND } \\
4.7 \\
5.8 \\
1.3 \\
\text { ND } \\
3.6 \\
1.4 \\
1.8 \\
2.5 \\
5.1 \\
7.7\end{array}$ & $\begin{array}{r}10 \cdot 0 \\
2 \cdot 2 \\
2 \cdot 2 \\
2 \cdot 9 \\
\text { ND } \\
\text { ND } \\
3 \cdot 6 \\
\text { ND } \\
\text { ND } \\
\text { ND } \\
2 \cdot 2 \\
2 \cdot 0 \\
3 \cdot 0 \\
4 \cdot 3\end{array}$ & $\begin{array}{r}11 \cdot 0 \\
1.9 \\
4 \cdot 2 \\
3.4 \\
\text { ND } \\
\text { ND } \\
2.9 \\
\text { ND } \\
\text { ND } \\
\text { ND } \\
1.5 \\
2.2 \\
2.2 \\
6.3\end{array}$ & $\begin{array}{r}3.4 \\
1.8 \\
4.4 \\
3.1 \\
\text { ND } \\
\text { ND } \\
2.4 \\
\text { ND } \\
\text { ND } \\
\text { ND } \\
1.2 \\
1.8 \\
3.5\end{array}$ \\
\hline $\begin{array}{c}\text { fCA type II } \\
29 \\
30 \\
31 \\
32 \\
33 \\
34 \\
35 \\
36 \\
37 \\
38 \\
39 \\
40 \\
41 \\
42\end{array}$ & $\begin{array}{l}H L A-B 27 \\
1.2 \\
1.7 \\
1.8 \\
0.2 \\
0.5 \\
2.0 \\
0.5 \\
1.5 \\
0.2 \\
0.2 \\
0.8 \\
0.6 \\
1.6 \\
1.9\end{array}$ & $\begin{array}{l}\text { gative } \\
13.0 \\
14.0 \\
11.0 \\
8.8 \\
17.0 \\
15.2 \\
0.5 \\
4.4 \\
0.4 \\
0.6 \\
0.2 \\
3.9 \\
3.4 \\
12.0\end{array}$ & $\begin{array}{r}7 \cdot 0 \\
2 \cdot 0 \\
6 \cdot 2 \\
2 \cdot 0 \\
9 \cdot 2 \\
21 \cdot 2 \\
1 \cdot 8 \\
2 \cdot 1 \\
1 \cdot 0 \\
0 \cdot 3 \\
0 \cdot 2 \\
9.0 \\
7 \cdot 6 \\
4 \cdot 8\end{array}$ & $\begin{aligned} 3 \cdot 8 \\
2 \cdot 8 \\
4.3 \\
1 \cdot 2 \\
11 \cdot 0 \\
8 \cdot 3 \\
0 \cdot 4 \\
1 \cdot 2 \\
0 \cdot 2 \\
0 \cdot 1 \\
0 \cdot 2 \\
1 \cdot 4 \\
3.6 \\
2.8\end{aligned}$ & $\begin{array}{c}4 \cdot 2 \\
\text { ND } \\
\text { ND } \\
1 \cdot 3 \\
6 \cdot 4 \\
\text { ND } \\
0 \cdot 6 \\
3.6 \\
0.8 \\
0.3 \\
\text { ND } \\
\text { ND } \\
\text { ND } \\
1.6\end{array}$ & $\begin{array}{r}5 \cdot 3 \\
\text { ND } \\
\text { ND } \\
2 \cdot 1 \\
3 \cdot 9 \\
\text { ND } \\
0 \cdot 9 \\
3 \cdot 3 \\
0 \cdot 8 \\
0.3 \\
\text { ND } \\
\text { ND } \\
\text { ND } \\
2 \cdot 0\end{array}$ & $\begin{array}{r}2 \cdot 0 \\
\text { ND } \\
\text { ND } \\
1 \cdot 0 \\
5 \cdot 1 \\
\text { ND } \\
0 \cdot 4 \\
2 \cdot 4 \\
0 \cdot 5 \\
0 \cdot 3 \\
\text { ND } \\
\text { ND } \\
\text { ND } \\
0 \cdot 7\end{array}$ \\
\hline
\end{tabular}

the children with pauciarticular JCA type II showed a specific synovial lymphocyte proliferation, nine to $Y$ enterocolitica and five to $C$ trachomatis. Table 3 gives detailed results for these patients. No specific proliferation was found to any of the other antigens. The percentage of patients with specific proliferation was significantly different in patients with pauciarticular JCA type II (50\%) from those with pauciarticular type I $(9 \%) \quad(p=0.01)$ (figure).

\section{CELLULAR IMMUNE RESPONSE TO BACTERIAL}

ANTIGENS IN PERIPHERAL BLOOD

Peripheral blood mononuclear cell responses to bacterial antigens in the children with arthritis did not show a significant difference compared with normal controls (table 4). The SI was always $<5$ except in patients Nos $21(\mathrm{SI}=20$ to $Y$ enterocolitica $), 39$ ( $\mathrm{SI}=9 \cdot 5$ to $B$ burgdorferi), and $10(10.0$ to $C$ trachomatis and 8.0 to $Y$ enterocolitica). As can be seen from table 3, however, in patients 21 and 39 no significant proliferation was found in synovial fluid to the triggering bacterium and in patient 10 there was a non-specific synovial response to $C$ trachomatis and $Y$ enterocolitica. Thus no evidence of a systemic immune response to bacterial antigens was seen in any of the specific responders in synovial fluid.

\section{HLA-B27 AND FEATURES OF}

\section{SPONDYLOARTHROPATHY}

The HLA-B27 antigen was determined in the 44 patients with pauciarticular JCA, psoriatic arthritis, and reactive arthritis and was positive in $16(38 \%)$. Two $(66 \%)$ of the patients with reactive arthritis and $14(50 \%)$ of the patients

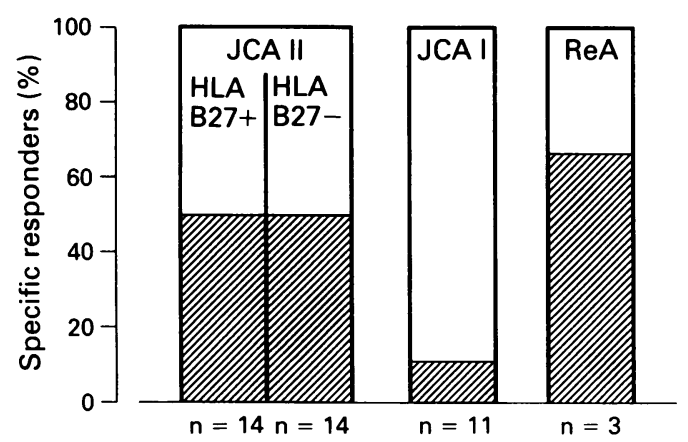

Percentage of specific responders (as defined under Patients and methods) to bacterial antigens in synovial fluid in juvenile chronic arthritis type I (FCA I), juvenile chronic arthritis type II ( $(C A$ II $)$, and reactive arthritis $(R e A)$. The hatched area represents the proportion of specific responders; the open area represents the non-specific responders or non-responders. $n=$ number of patients.

Table 4 Peripheral blood lymphocyte response to yersinia $(Y E)$, chlamydia $(C T)$, borrelia $(B B)$, salmonella $(S A)$, shigella $(S H)$ and campylobacter $(C \mathcal{F})$ in patients with reactive arthritis $(R e A)$ and juvenile chronic arthritis $(\mathcal{F C A})$. Results given as mean $(S D)$ stimulation index

\begin{tabular}{lllllll}
\hline Patient group & $Y E$ & $C T$ & $B B$ & $S A$ & $S H$ & $C \mathcal{1}$ \\
\hline Reactive arthritis & $2 \cdot 1(1 \cdot 5)$ & $0 \cdot 8(0 \cdot 4)$ & $1 \cdot 9(1 \cdot 5)$ & $0 \cdot 4$ & $0 \cdot 3$ & $0 \cdot 4$ \\
JCA type I & $1 \cdot 7(2)$ & $1 \cdot 8(2 \cdot 7)$ & $1 \cdot 7(1 \cdot 3)$ & $1 \cdot 6(0 \cdot 4)$ & $1 \cdot 2(0 \cdot 4)$ & $1 \cdot 1(0 \cdot 4)$ \\
JCA type II HLA-B27 positive & $3 \cdot 3(5)$ & $1 \cdot 8(2 \cdot 1)$ & $2 \cdot 6(3 \cdot 4)$ & $2 \cdot 2(1 \cdot 9)$ & $2 \cdot 3(1 \cdot 8)$ & $1 \cdot 9(1 \cdot 7)$ \\
JCA type II HLA-B27 negative & $1 \cdot 4(0 \cdot 7)$ & $1 \cdot 3(0 \cdot 7)$ & $1 \cdot 8(0 \cdot 8)$ & $1 \cdot 1(0 \cdot 4)$ & $1 \cdot 2(0 \cdot 5)$ & $1 \cdot 1(0 \cdot 4)$ \\
Healthy controls & $3 \cdot 2(2 \cdot 7)$ & $1 \cdot 8(1 \cdot 5)$ & $3 \cdot 5(2 \cdot 8)$ & $2 \cdot 6(2 \cdot 9)$ & $1 \cdot 3(1 \cdot 2)$ & $0 \cdot 9(0 \cdot 8)$ \\
\hline
\end{tabular}


with JCA type II but none of the patients with psoriasis or JCA type I were positive (table 1). In the 28 patients with JCA type II a similar proportion of HLA-B27 positive patients (seven of 14) and HLA-B27 negative patients (seven of 14) were specific responders (figure, table 3 ). The presence of clinical features suggestive of spondyloarthropathy (in patients 15,23 , and 24 of the JCA type II HLA-B27 positive patients and in patients 32 and 34 of the HLA-B27 negative patients) also did not correlate with a specific response. Three such patients were non-specific responders or non-responders and two were specific responders.

\section{HUMORAL IMMUNE RESPONSES}

In none of the patients with psoriatic arthritis and JCA type I were antibodies against the bacteria tested found. In reactive arthritis and JCA type II one and five patients had antibodies to $Y$ enterocolitica and one patient in each of these groups had antibodies to $C$ trachomatis. Four of nine patients $(56 \%)$ with a $Y$ enterocolitica specific synovial cellular immune response had increased antibodies to $Y$ enterocolitica (patient $\mathbf{l}$ in the group with reactive arthritis). No patient with a $C$ trachomatis specific response had antibodies against $C$ trachomatis. This was also true for patient 2 with reactive arthritis who had a symptomatic preceding urethritis. There was no significant difference between the antibody titres in synovial fluid and peripheral blood (data not shown). Of the nine normal controls, none had antibodies against $C$ trachomatis and only two against $Y$ enterocolitica. Thus there was no significant difference in antibody titres among the various groups.

\section{Discussion}

There are cogent reasons why organisms associated with reactive arthritis might play an important part in JCA. Paramount among these is the clinical similarity between reactive arthritis and pauciarticular JCA, particularly of the late onset type II variety. In this paper we present evidence that not only childhood reactive arthritis but also some cases of pauciarticular JCA might be due to pathogens such as $Y$ enterocolitica and $C$ trachomatis which have been shown to play an aetiological part in adult reactive arthritis and undifferentiated oligoarthritis. ${ }^{262932}$

Seventeen of the 44 children (39\%) with oligoarthritis examined showed a $C$ trachomatis or $Y$ enterocolitica specific response in synovial lymphocyte proliferation assays. Two of the three patients with classical reactive arthritis responded to bacteria (one to $Y$ enterocolitica and one to $C$ trachomatis) whereas two control patients with psoriatic arthritis did not. Most importantly, an antigen specific response was also found in patients with pauciarticular JCA; 14 of the 28 type II children (50\%) responded specifically to $C$ trachomatis or $Y$ enterocolitica but only one of the 11 children (9\%) with type I JCA showed a specific response. We did not study patients with systemic or polyarticular disease. The results of the study, which are in good agreement with our study of oligoarthritis in adults, ${ }^{23}$ support the idea that a proportion of children with JCA type II have a forme fruste of reactive arthritis similar to adult undifferentiated oligoarthritis. The limited number of positive control patients with classical reactive arthritis reflects the relative rarity of clearly defined cases in children, especially with large knee effusions. The negative controls (patients with psoriatic arthritis) are also few but, again, children with large effusions are uncommon. The specific nature of the responses we found is, however, supported by the rarity of a specific response in the patients with pauciarticular JCA type $\mathbf{I}$.

One difficulty in interpreting the lymphocyte proliferation test is that a considerable proportion of patients show non-specific reactivity, that is an equivalent response to several organisms. To distinguish between non-specific reactivity and a specific response to a putative aetiological agent, we defined stringent criteria for a specific response which are described in detail under Patients and methods. There are several explanations for the demonstration of non-specific reactivity (reviewed by Kingsley and Panayi ${ }^{16}$ ) including cross reactive antigens between enterobacteriaceae $^{32}$ or between human and bacterial antigens, ${ }^{15}$ high monocyte numbers in synovial fluid ${ }^{40}$ and non-specific recruitment into the joint of memory lymphocytes sensitised in previous infections. ${ }^{41}$ Sixty five per cent of the children with pauciarticular arthritis who did not respond specifically to a single antigen showed such non-specific reactivity. Apart from the mechanisms described here, such a generalised response could also arise as a result of increased reabsorption of bacterial antigens due to enhanced gut permeability. The demonstration of asymptomatic chronic gut inflammation in most patients with pauciarticular $\mathrm{JCA}^{42}$ provides some support for this concept.

There have previously been few similar studies in children, perhaps because of the difficulty of obtaining synovial fluid. Southwood et $a l^{43}$ also showed synovial $T$ cell responses to infective agents in over $50 \%$ of children with unselected JCA. They found responses to $Y$ enterocolitica, salmonella, and to influenza $\mathrm{A}$ but not to $C$ trachomatis. Unlike our study they did not differentiate between specific and non-specific reactivity nor among the various JCA subgroups so that the interpretation of the results from an aetiological perspective is difficult. In another investigation reactivity to human hsp60 was found in $60 \%$ of children with JCA, mainly in HLA-B27 negative, antinuclear antibody positive children. ${ }^{44}$ This may delineate a different aetiological group from the bacterial responders in our study.

On clinical grounds it has long been thought that some of the children with pauciarticular type II might have unrecognised reactive arthritis as they often have self limiting disease, sometimes with features of spondyloarthropathy such as enthesitis or dactylitis. Our study provides some evidence to support this concept. It is also clear that some children with type II JCA go on to develop ankylosing spondylitis or other defined spondyloarthropathy which have 
an entirely different prognosis. The synovial cellular immune response may help to differentiate those with cryptic reactive arthritis from other patients. Somewhat unexpectedly, we did not find that specific lymphocyte proliferation correlated with the possession of the HLA-B27 antigen. Southwood et al $^{45}$ did find that HLAB27 positive patients responded better to bacterial antigens. This difference may be explained in that, unlike our study, they did not separate specific and non-specific responses to bacteria. The presence of symptoms suggestive of spondyloarthropathy also did not correlate with a specific lymphocyte response in our study, possibly because such clinical features are also present in other spondyloarthropathy such as ankylosing spondylitis and psoriatic arthritis where bacteria associated with reactive arthritis are probably not relevant. ${ }^{29}$

In our study the most common pathogen was $Y$ enterocolitica (11 specific responders) whereas six patients responded specifically to $C$ trachomatis. The demonstration of a specific response to $Y$ enterocolitica is less surprising than the finding of a $C$ trachomatis specific response. Reactive arthritis induced by enteric infection is well recognised in children and $Y$ enterocolitica and salmonella are important pathogens, though other organisms may play a part. ${ }^{4} 1819$

As $C$ trachomatis is normally transmitted by sexual intercourse, $C$ trachomatis induced reactive arthritis would be expected to be rare in childhood; however, a few cases have been reported. $^{20} 21 \mathrm{~A}$ possible explanation for our results is that Chlamydia pneumoniae rather than Chlamydia trachomatis is the causative agent as there is cross reactivity in $\mathrm{T}$ cell responses of the different species. Chlamydia pneumoniae is a common cause of respiratory tract infections in adults and children ${ }^{46}$ and a role for it in reactive arthritis has been shown. ${ }^{47} \mathrm{With}$ respect to this, we tested our patients for antibodies against a wide array of chlamydial subtypes as they are serologically distinct, but none was positive. Chlamydia could also be transmitted at birth from mother to infant via the vagina ${ }^{48}$ or sexually, either through voluntary sexual contact in older children or sexual abuse. ${ }^{49} 50$ Transmission of $C$ trachomatis, probably by hand, from the urogenital tract of infected parents to their children has also been reported. ${ }^{21}$ Our data suggest that chlamydia might play a pathogenetic part in JCA, though the site of the initiating infection is not clear.

The absence of antibodies to chlamydia and the low occurrence of antibodies to $Y$ enterocolitica (found in $57 \%$ of patients with a $Y$ enterocolitica antigen specific cellular response) confirms in children what has already been shown in adults, namely that patients with active reactive arthritis may not have a humoral response. 2829

In summary, our results emphasise the possible role of infectious triggers, in this instance bacteria, in childhood arthritis and suggest that pauciarticular JCA type II, which clinically resembles reactive arthritis, may often be an occult form of that disease. The most important pathogens in this cryptic form of reactive arthritis appear, as in adults in Germany, to be yersinia and chlamydia. ${ }^{23}$ Such information is becoming increasingly important in view of the various studies supporting the use of long term antibiotic treatment in patients with arthritis precipitated by bacterial agents. ${ }^{51}$ Our study also serves to substantiate the idea that JCA is T cell mediated and that each type may have a distinct aetiology.

This work was supported by the Bundesministerium für Forschung und Technologie, Germany and the British/German Academic Research Collaboration Programme (British Council DAAD). We are grateful to Professor A Mitchison from Deutsches Rheumaforschungszentrum Berlin for advice and support. We also thank Marion Berger for technical assistance.

1 Wood P H N. Special meeting on: nomenclature and classification of arthritis in children. In: Munthe E, ed. The care of rheumatic children. EULAR monograph series no 3. Basle: Eular, 1978: 47-50.

2 Cassidy J T, Levinson J E, Bass J C, et al. A study of classification criteria for a diagnosis of juvenile rheumatoid arthritis. Arthritis Rheum 1986; 29: 274-81.

3 Schaller J G. Chronic arthritis in children. Clin Orthop 1984; 182: 79-89.

4 Michels H, Häfner R, Morhart R, Schuchmann L, Truckenbrodt $\mathbf{H}$. Five year follow-up of a prospective cohort of juvenile chronic arthritis with recent onset. Clin Rheumatol juvenile chronic

5 Hussein A, Abdul-Khaligs H, von der Hardt H. Atypical spondyloarthritis in children: proposed diagnostic criteria Eur f Pediatr 1989; 148: 513-7.

6 Lang B A, Shore A. A review of current concepts on the pathogenesis of juvenile rheumatoid arthritis. $\mathcal{F}$ Rheumatol Suppl 1990; 21: 1-15

7 Odum N, Morling N, Platz P, et al. Increased prevalence of late stage $T$ cell activation antigen (VLA-1) in active juvenile chronic arthritis. Ann Rheum Dis 1987; 46: 846-52.

8 De Maria A F, Malnati M S, Poggi A, Pende D, Cottafava F Moretta L. Clonal analysis of joint fluid T lymphocytes in patients with juvenile rheumatoid arthritis. $\mathcal{f}$ Rheumato 1990; 17: 1073-8.

9 Leak A M. Autoantibody profile in juvenile chronic arthritis. Ann Rheum Dis 1988; 47: 178-82.

10 Nepom B S, Malhotra U, Schwarz D A, Nettles J W, Schaller J G, Concannon P. HLA and T cell receptor polymorphism in pauciarticular-onset juvenile rheumatoid arthritis. Arthritis Rheum 1991; 34: 1260-7.

11 Denman $A$ M. A viral aetiology for juvenile chronic arthritis? Br F Rheumatol 1988; 27: 169-75

12 Chantler J K, Tingle A J, Petty R E. Persistent rubella virus infection associated with chronic arthritis in children $N$ Engl f Med 1985; 313: 1117-23.

13 Pritchard M H, Matthews N, Munro J. Antibodies to influenza $A$ in a cluster of children with juvenile chronic arthritis. $B r \mathcal{F}$ Rheumatol 1988; 27: 176-80.

14 Burgos-Vargas R, Howard A, Ansell B M. Antibodies to peptidoglycan in juvenile onset ankylosing spondylitis and pauciarticular onset juvenile arthritis associated with pauciarticular onset juvenile arthritis associated
chronic iridocyclitis. $f$ Rheumatol 1986; 13: 760-2.

15 de Graeff-Meeder E R, van der Zee R, Rijkers G T, et al. Recognition of human $60 \mathrm{kd}$ heat shock protein by mononuclear cells from patients with juvenile chronic arthritis. Lancet 1991; 337: 1368-72.

16 Kingsley G, Panayi G S. Antigenic responses in reactive arthritis. Rheum Dis Clin North Am 1992; 18: 49-66.

17 Keat A. Reiter's syndrome and reactive arthritis in perspective. N Engl f Med 1983; 309; 1606-15.

18 Rosenberg A M. Analysis of a pediatric rheumatology clinic population. I Rheumatol 1990; 17: 827-30.

19 Kunnamo I, Kallio P, Pelkonen P, Hovi T. Clinical signs and laboratory tests in the differential diagnosis of arthritis in children. Am $\mathcal{F}$ Dis Child 1987; 141: $34-40$.

20 Rosenberg A M, Petty R E. Reiter's disease in children. Am $\mathcal{F}$ Dis Child 1979; 133: 394-8.

21 Gough K R. Reiter's syndrome in father and son. Ann Rheum Dis 1962; 21: 292-4.

22 Arnett F C. The Lyme spirochete: another cause of Reiter's syndrome? Arthritis Rheum 1989; 32: 1182-4.

23 Sieper J, Braun J, Brandt J, et al. Pathogenetic role of Chlamydia, Yersinia and Borrelia in undifferentiated oligoarthritis. $\mathcal{F}$ Rheumatol. In press.

24 Ford D K, daRoza D M, Ward R H. Arthritis confined to knee joints. Arthritis Rheum 1984; 27 : 1157-64.

25 Keat A C, Knight S C. Do synovial fluid cells indicate the cause of reactive arthritis? I Rheumatol 1990; 17: 1257-9.

26 Keat A, Thomas B, Dixey J, Osborn M, Sonnex C, TaylorRobinson D. Chlamydia trachomatis and reactive arthritis: the missing link. Lancet 1987; i: 72-4.

27 Granfors $\mathrm{K}$, Jalkanen S, vonEssen $\mathrm{R}$, et al. Yersinia antigens in synovial fluid cells from patients with reactive arthritis. $N$ Engl F Med 1989; 320: 216-21.

28 Dattwyler R, Wolkman D, Luft B, Halperin J J, Thomas D Golightly M G. Seronegative Lyme disease: dissociation of Golightly $M$ G. Seronegative Lyme disease: dissociation of
specific $T$ and B-lymphocyte responses to Borrelia specific $T$ and B-lymphocyte responses to
burgdorferi. $N$ Engl f Med 1988; 319: 1441-6.

29 Sieper J, Kingsley G, Palacios-Boix A, et al. Synovial T lymphocyte specific immune response to Chlamydia trachomatis in Reiter's disease. Arthritis Rheum 1991; 34 588-98. 
30 Heesemann J, Eggers C, Schroeder J. Serological diagnosis of Yersiniosis by immunoblot technique using virulence associated antigen of enteropathogenic yersiniae. Contrib Microbiol Immunol 1987; 9: 285-9.

31 Ford D K, daRoza D M, Shah P, Wenman W M. Cellmediated immune responses of synovial mononuclear cells in Reiter's syndrome against ureaplasmal
antigens. $\mathcal{F}$ Rheumatol $1980 ; 7: 751-5$.

32 Gaston J S H, Life P F, Granfors K, et al. Synovial T lymphocyte recognition of organisms that trigger reactive arthritis. Clin Exp Immunol 1989; 76: 348-53.

33 Khan M A, van der Linden S M. Undifferentiated spondylarthropathies. In: Khan $M$, ed. Spine: state of the art reviews. Ankylosing spondylitis and related spondylarthropathies. Vol. 4. 1990: 657-64.

34 Dougados $M$, van der Linden S, Juhlin $R$, et al. The European spondylarthropathy study group preliminary European spondylarthropathy study group preliminary
criteria for the classification of spondylarthropathy. Arthritis Rheum 1991; 34: 1218-27.

35 Salari S H, Ward M E. Polypeptide composition of Chlamydia trachomatis. F Gen Microbiol 1981; 123: 197-207.

36 Schoenberg A, Camey C, Kahl O, Wilske B, Praec-Mursic V, Hovind-Hougen K. First isolation of Borrelia burgdorferi, the agent of Lyme Borreliosis, from Ixodes ricinus in Berlin. Zentralbl Bakteriol Mikrobiol Hyg $(A)$ 1988; A268: 487-94.

37 Treharne J D, Darougar S, Jones B R. Modification of the microimmunofluorescence test to provide a routine serodiagnostic test for chlamydial infections. 7 Clin Pathol 1977; 30: 510-7.

38 Craft J E, Grodzicki R L, Steere A C. Antibody response in Lyme disease. Evaluation of diagnostic tests. F Infect Dis 1984; 149: 789-95.

39 Terasaki P I, Bernoco D, Park M S, Ozturk G, Iwaki Y. Microdroplet testing for HLA A, B, C and D antigens. Am Microdroplet testing for HLA A

40 Sieper J, Braun J. The synovial T cell response to chlamydia and yersinia in reactive arthritis becomes more specific by optimized ratios of mononuclear cells. Clin Rheumato 1990; 9: 585 .

41 Pitzalis C, Kingsley G, Haskard D, Panayi G S. The preferential accumulation of helper-inducer $\mathrm{T}$ lymphocytes in inflammatory lesions: evidence for regulation by selective endothelial and homotypic adhesion. Eur $\mathcal{F}$ Immunol 1988; 18: $1397-404$.

42 Mielants H, Veys E M, Joos R, Cuvelier C, de Vos M, Proot F. Late onset pauciarticular juvenile chronic arthritis. Felation to gut inflammation. 7 Rheumatol 1987; 14: Relation

43 Southwood T R, Bailey L C, Gaston J S H. Specificity of proliferative responses of synovial fluid and peripheral blood from patients with juvenile arthritis. Arthritis Rheum 1990; 33: S14.

44 de Graeff-Meeder E R, van der Zee R, Voorhorst-Ogink M M, et al. HSP 60 and juvenile chronic arthritis. Arthritis Rheum 1991; 34: S151.

45 Southwood T R, Hassell A, Gaston I S H. Antigen-induced lymphocyte proliferation in HLA B27+ juvenile arthritis patients. Arthritis Rheum 1991; 34: S152.

46 Grayston J I, Campbell L A, Kuo C C, et al. A new respiratory tract pathogen: Chlamydia pneumoniae strain TWAR. F Infect Dis 1990; 161: 618-25.

47 Saario R, Toivanen A. Chlamydia pneumoniae as a cause of reactive arthritis. Clin Rheumatol 1992; 11: 161.

48 Harrison H R. Chlamydial infection in neonates and children. In: Oriel D, Ridgway G, ed. Chlamydial infections. Proceedings of the 6th intermational symposium on human chlamydial infections. Cambridge: Cambridge University Press, 1986: infections.

49 Shafer M A, Prager V, Shalwitz J, et al. Prevalence of urethral Chlamydia trachomatis and Neisseria gonorrhoeae among asymptomatic, sexually active adolescent boys. f Infect Dis 1987; 156: 223-4.

50 Ingram D L, Runyan D K, Collins A D, et al. Vaginal Chlamydia trachomatis infection in children with sexual contact. Pediatr Infect Dis $\mathcal{F}$ 1984; 3: 97-9.

51 Lauhio A, Leirisalo-Repo M, Lähdevirta J, Saikku P, Repo $H$. Double-blind, placebo-controlled study of three-month treatment with lymecycline in reactive arthritis with special reference to Chlamydia arthritis. Arthritis Rheum 1991; 34: 6-14. 